\title{
Bridge assessment: A case study of Ajaokuta-Itobe Bridge, Kogi State Ibrahim
}

\author{
AInuwa *, Abubakar Musa Yola, Hassan Abba Musa, Victor Mlanga and Umar Shuaibu \\ Nigerian Building \& Road Research Institute, NBRRI House 10 I.T. Igbani Street, Off Obafemi Awolowo Way, Jabi PMB \\ 5065 Abuja, FCT, Nigeria.
}

World Journal of Advanced Engineering Technology and Sciences, 2021, 02(02), 066-078

Publication history: Received on 10 April 2021; revised on 19 May 2021; accepted on 22 May 2021

Article DOI: https://doi.org/10.30574/wjaets.2021.2.2.0040

\begin{abstract}
This report summarizes the assessment carried out as a result of the public uproar on the degree of safety of the Ajaokuta/Itobe Bridge in Kogi state. The public outcry was as a result of a severe damaged expansion joints of the bridge. Visual inspection and concrete strength test were carried out to ascertain the safety condition of Itobe Bridge. Seven out of the total number of eight expansion joint covers were damaged and out of place while all the elastomeric bearings were in good working condition. The scouring of the river bed was not visually pronounced except little at the abutment side of the Abuja-Ayingba approach which is attributed to change of water course. Farming activities within the vicinity of the bridge embankment has no effects on the bridge foundation. The compressive strength test result of some bridge elements selected shows that the values are within the satisfactory range. The assessment recommended the lengthening and desilting of the drainage pipes to prevent further corrosion of the concrete and steel members. The use of sand blasting and repainting of the steel beams was also recommended to protect them from further corrosion. Maintenance of cracks on the reinforced concrete abutment and piers should be carried out. The use of sheet piles filled with compacted sand or gabions around the exposed piles caps to protect the foundation was recommended. Shoreline protection measures should be used in protecting the bridge eroded embankment. Seven out of eight expansion joint devices were damaged therefore exposing the elements of the structure that are otherwise protected by the joint devices. The openings about $47 \mathrm{~cm}-53 \mathrm{~cm}$ becomes a conduit by which moisture, abrasives, chemicals, and other debris are deposited on the superstructure and substructure below the opening, thereby causing extensive damage. The expansion joints devices should be fixed with proper elastomeric strip seal to protect the bridge from further deterioration.
\end{abstract}

Keywords: Elastomeric; Scouring; Abutment; Embankment; Abrasives

\section{Introduction}

The United States National Bridge Inspection Standards (NBIS, 2012) in their (Bridge Inspectors Reference Manual) defines a bridge as a structure including supports erected over a depression or an obstruction, such as water, highway, or railway, and having a track or passageway for carrying traffic or other moving loads, and having an opening measured along the centre of the roadway of more than 6.09 metres between undercopings of abutments or spring lines of arches, or extreme ends openings for multiple boxes; it may also include multiple pipes, where the clear distance between openings is less than half of the smaller contiguous opening. From the foregoing, it is understood that bridges provide easy access to regions that may otherwise be inaccessible. Thus regions with good transport infrastructure such as bridges seem to be better-connected and ultimately enjoy overall growth or development; whereas regions of less wellconnected appear to lag behind in term of socio-economic enhancement (Tompsett, 2014). In addition, bridges bring about clear economies of density for communities close to the bridge will have lower trade costs with the other side,

${ }^{*}$ Corresponding author: Ibrahim A Inuwa

Nigerian Building \& Road Research Institute, NBRRI House 10 I.T. Igbani Street, Off Obafemi Awolowo Way, Jabi PMB 5065 Abuja, FCT, Nigeria. 
thus trades agglomerate near the bridge and trading city emerges; because naturally people move close to trading opportunities to minimize trading costs as well as strive to exploit economies of density in transportation technology (Roc, Miklos and David, 2014). Now, one could decipher that bridge infrastructure provision brings about prosperity to a geographical location because accessibility is made easier, although it is capital intensive to provide; hence the need to maintain and sustain those that have been made available. Bridges having been one of the most exposed physical infrastructures to climatic dynamics such as variation in temperatures, moisture, e.t.c., thus the bridge components undergo some physical dilapidations like wearing, tiring and corrosion, which affect the life span of the infrastructure. Consequently, to prolong the life span of a bridge, there is the need to routinely inspect drainage systems, expansion joints, bearing assemblies, beams, seats, caps, embankments, piers and other critical members of the bridge (Iowa DOT, 2011)

The Itobe Bridge is situated across River Niger in Kogi State Nigeria; the bridge has a great importance to the Nigerian economic, social and financial benefits as it links the northern and the eastern part of the country. Failure of the bridge will be disastrous to the users as it will halt the commercial movement thereby affecting the country's economy.

The aim of this assignment is to prepare an assessment report on Itobe Bridge in order to assess its current condition, overall safety, and performance of the bridge structure, identification of any major defect or incident and any steps that might be required to secure its future durability and to design predictive maintenance for the bridge. To this effect, a team of research officers was delegated by the Acting Director-General/Chief Executive Officer of NBRRI to provide appropriate recommendations to avert collapse of the bridge.

\section{Background information}

Itobe town is located in Ajaokuta Local Government of Kogi State. It is about 45km south ward of Lokoja, Kogi state capital. Through which a major express road from the north, passing through Ajaokuta to Ayingba and linking the eastern part of the country. There are several major roads dissecting the area. One leads to Lokoja, which is a link to the southwestern part of the country. Ajaokuta is bounded to the east by river Niger. Itobe/Ajaokutabridge is a reinforced concrete (Haunched Box Girder) bridge built across River Niger by Julius Berger group of company in 1985.The study area is between latitude and longitudes $7^{\circ} 25^{\prime} 53.56^{\prime \prime} \mathrm{N}, 6^{\circ} 42^{\prime} 9.33^{\prime \prime E}$ just 2 kilometers away from Ohunene community. It has total length of 2,890metres, consisting of 8 expansion joints spanning at about 361meters apart and 66,740 square meters of surface area carrying dual carriageway of $18 \mathrm{~m}$ total width per lane (including median and walkway) on A2 Highway of Nigeria. Aerial views of the Ajaokuta Bridge can be observed in the plate 2

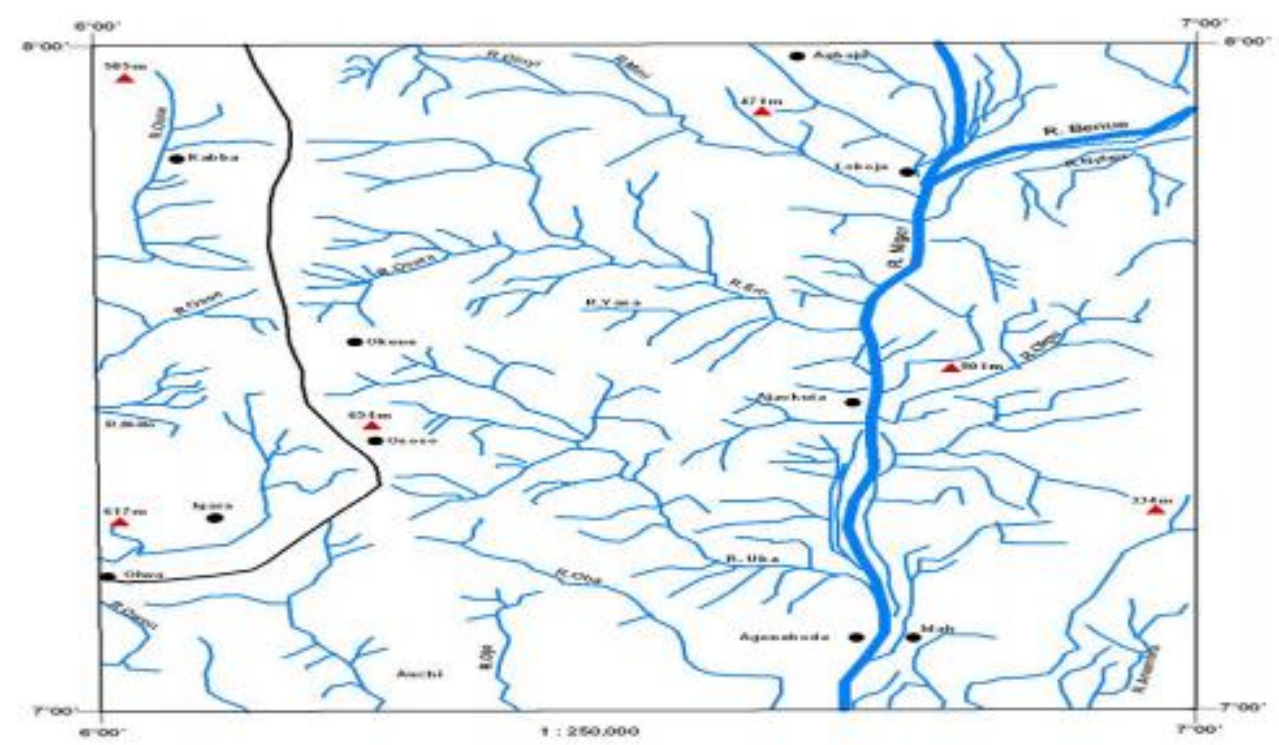

Plate1 Lower River Niger drainage system with its tributaries along Lokoja Area.

(GSN,1986)

Ajaokuta and it environment has a unique topography which is very rugged,with numerous undulating hills and steep/scarp slopes. Ajaokuta is in tropical hinterland with moderate rainfall between 1000-1500 per annum. The 
relative humidity is 40\%-60\% in January (dry season) and 60-80\% in July in the morning, $50-70 \%$ in the afternoon(Samuel. 0. Oni,2014). River Niger arises from Fouta Djallon highland arriving in Nigeria through Kebbi State and flows through to the Atlantic Ocean. The study location is within the extends of River Niger stretch traversing Ajaokuta area in the lower River Niger regime, which is georeferenced within the Lokoja - Okene area delimited by latitudes $7^{\circ}$ and $8^{\circ} \mathrm{N}$ and longitudes $6^{\circ}$ and $7^{\circ} \mathrm{E}$. Lower River Niger is drained by the Niger-Benue River system, which stretches beyond Lokoja down to the Niger Delta where it empties its content into the Atlantic Ocean. Contribution from watershed tributary streams and rivers to the east and west flowing north-south is significant (plate 1). However, the hydrologies of discharges from the tributaries are grossly changeable and inundating during rainy season to almost completely dry cut in the course of the dry season (GSN, 1986). Activities on lower River Niger around Ajaokuta include fishing, transportation and domestic uses by communities along the bank of the river. A power station and steel production company seats along the bank of River Niger at Geregu and Ajaokuta.

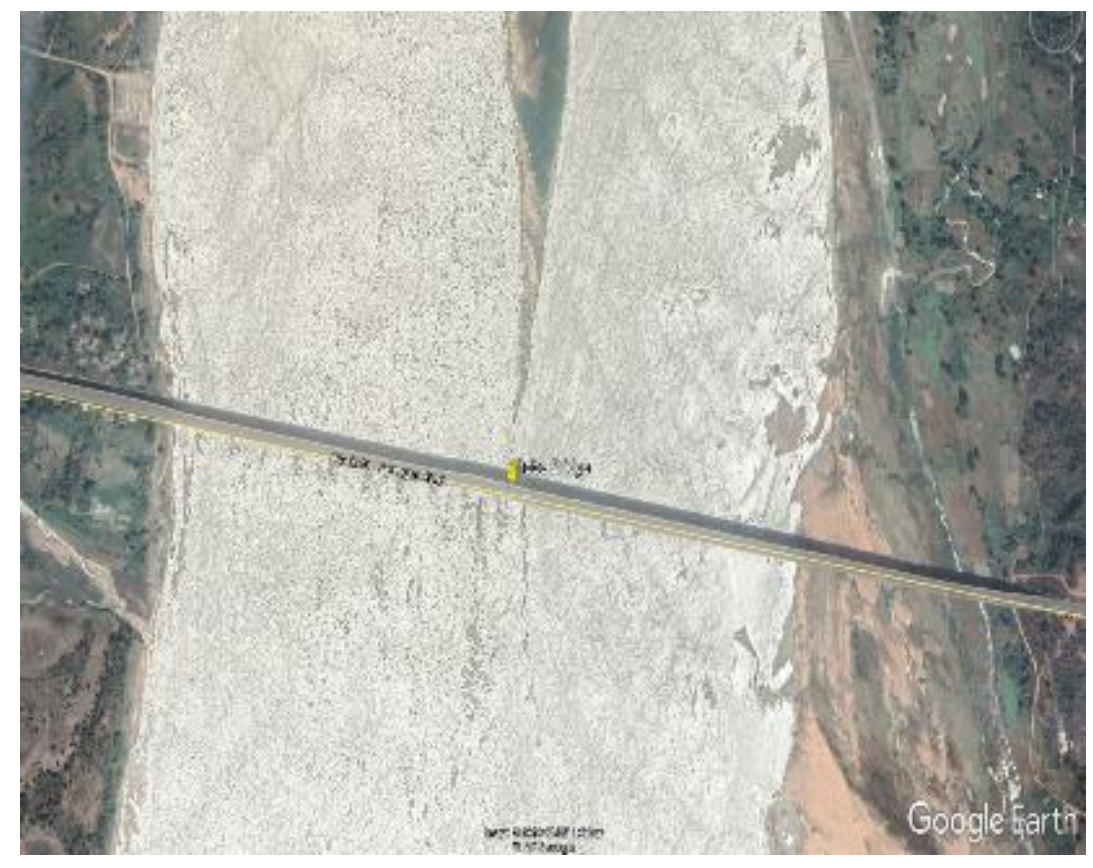

Plate 2Showing location of Itobe Bridge from google maps

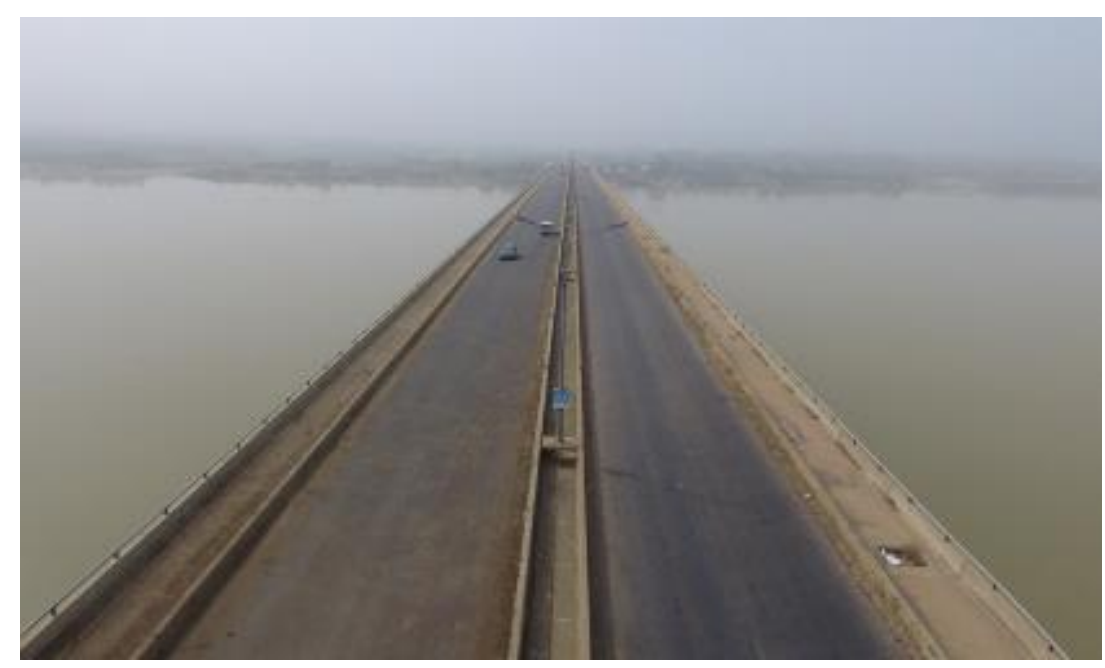

Plate 2 Drone imagery showing top view of Itobe Bridge 


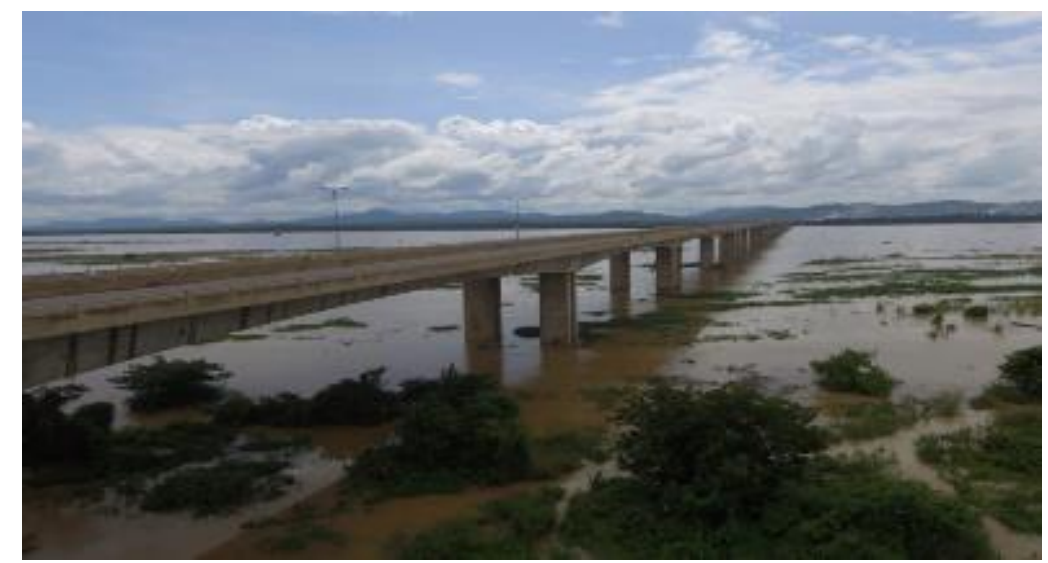

Plate 3Drone imagery showing side view of Itobe Bridge

\subsection{Site Visit}

The team of Engineers arrived at the bridge location on the 6th of January, 2020. The extensive investigative exercise then lasted for two days, concluding on the 7th January, 2020. Drone-aided visual inspection and structural integrity assessment (compressive test) were carried out on the bridge with the view to gather any relevant information for further study and compilation.

\section{Material and methods}

\subsection{Material}

The equipment used for the investigations include: DJI Phantom 3 Sport Edition drone, Digital cameras, Measuring tapes, Surveyors Wheels, Crack width gauges, Binoculars, Gilson Schmidt Concrete Test Hammers, Handheld GPS, First Aid Kits.

\subsection{Method}

In order to collect adequate information about the bridge, the following procedures were taken:

\subsubsection{Measurement}

Measurements and sketches of the existing bridge were carried out to be used as a reference since the as-built drawings were not available, see appendix A.

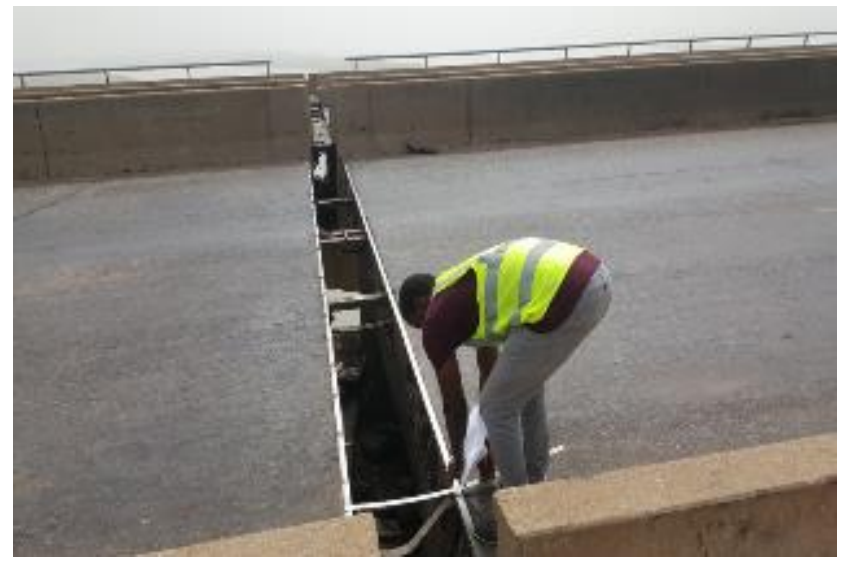

Plate 4Measurement of exposed expansion joint

\subsubsection{Integrity Test}

Non-Destructive Test (NDT)structural integrity tests were conducted on some selected bridge components using Gilson Schmidt Concrete Test Hammer to determine the compressive strength of the concrete. The structural integrity tests 
enable the collection of critical data with a high degree of accuracy to help in determining the serviceability state of the structure.

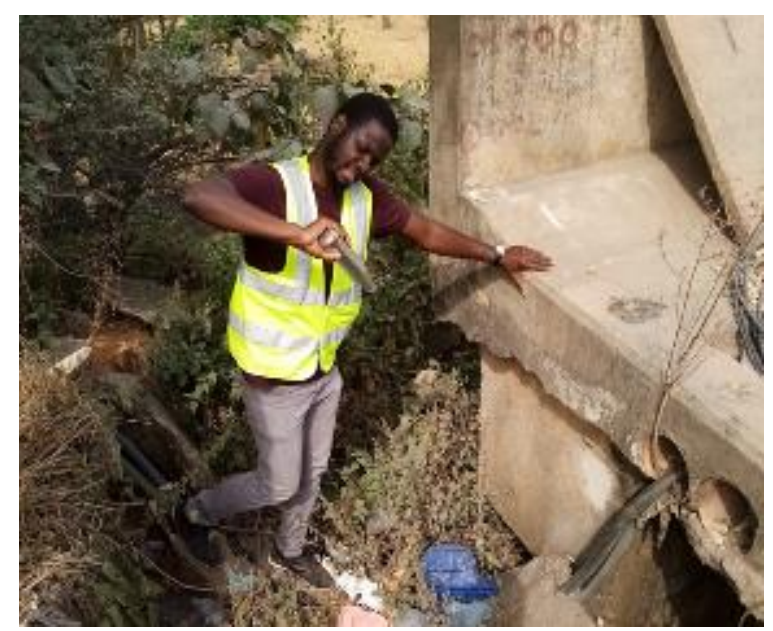

Plate 6 Concrete strength test using rebound hammer device on Bridge Abutment

\subsubsection{Mining Activities}

Investigation into mining activities in the area was carried out, as this was assumed to contribute to scouring of the river bed. In this section, two approaches of data collections were made. The first approach was personal interview with the people in the community to be sure if mining activities took place in the past or are currently taking place on the site. The second approach was the soil samples collection to determine the soil type at suspected mining pits.

\section{Results and Discussion}

\subsection{Visual inspection of Haunched Box Girder (Reinforced Concrete) Bridge}

\subsubsection{Exposed Reinforcement}

The reinforcement and wire mesh were exposed at the bottom of bridge deck towards Abuja approach which showed sign of early state of corrosion at certain places as shown in Plate 7 below. This was due to extensive fire impact as a result of burnt trees under the deck. The corrosion of the reinforced bars may be as a result of damaged/blocked drainage pipe as shown in picture below.
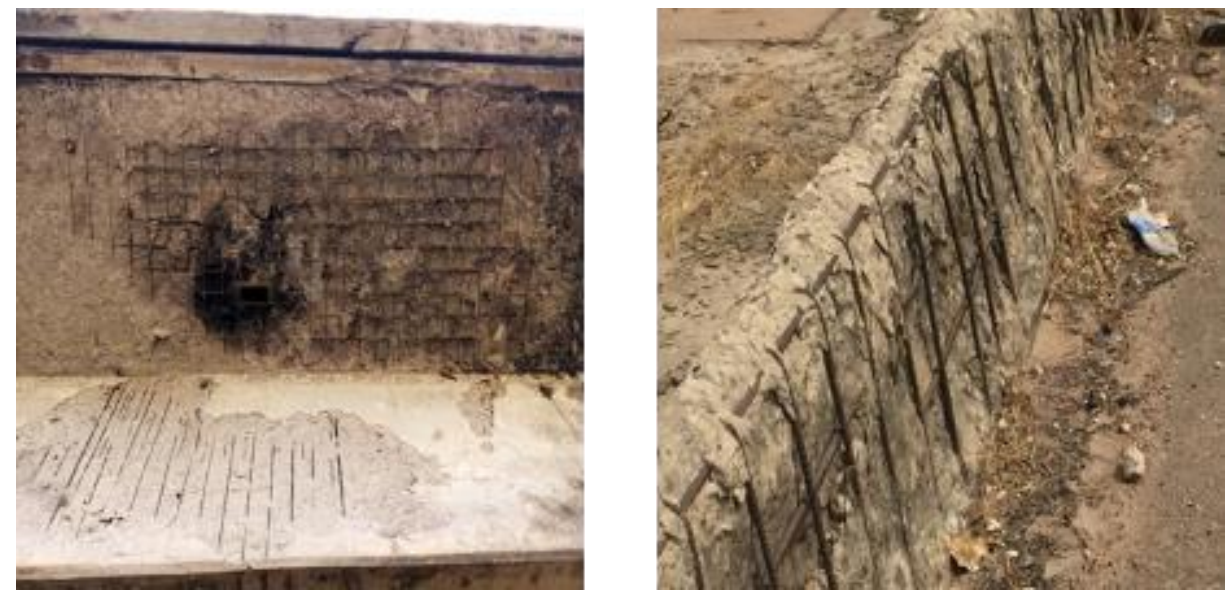

Plate 7 Corrosion of reinforcement bars at the soffit of deck.

The intensity of the fire also affected the deck barrier at the top of the deck. This resulted in spalling of the concrete cover as shown in figure 8. 


\subsubsection{Scouring}

Scouring is the engineering term for the erosion of soil surrounding a bridge foundation (pile caps and abutments). Bridge scour occurs when fast-moving water around a bridge removes sediment from the bridge foundation, leaving behind scour holes. In the case of Itobe Bridge there was no visible scour action around the bridge substructure except at span No2, Ayingba approach, as shown in Plate 9. Erosion and gradual wash out was observed at some part of Abuja approach embankment as shown in Plate 10 below.
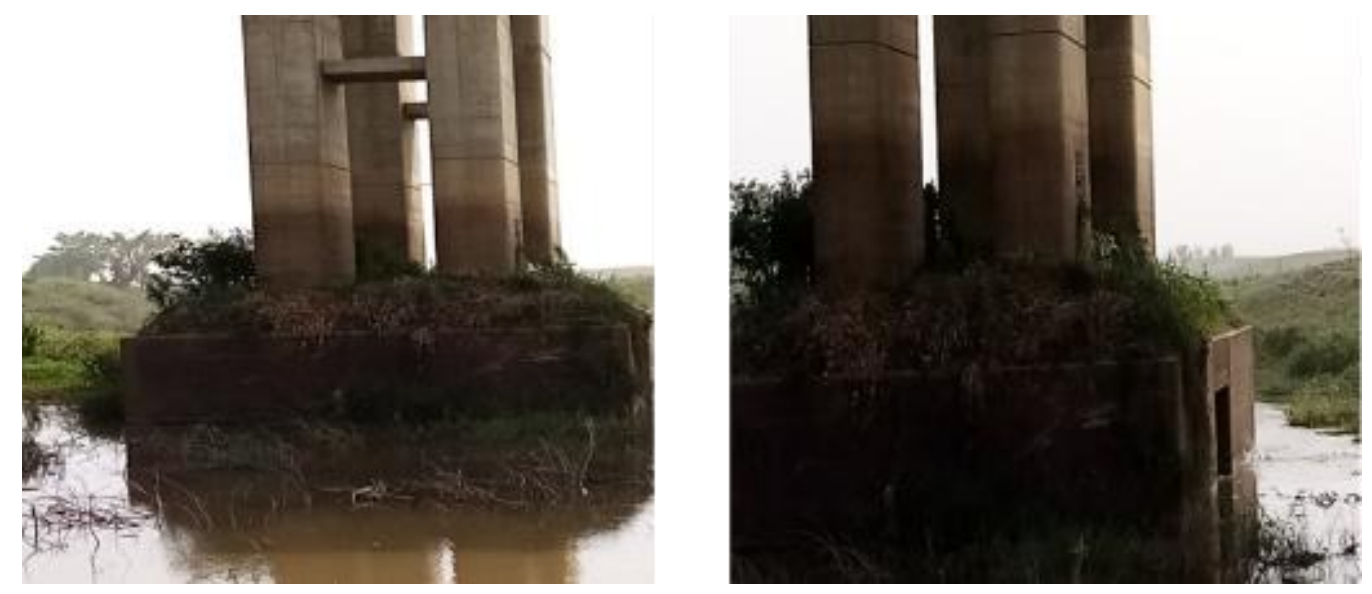

Plate 9Scouring action exposing the pile cap No 2
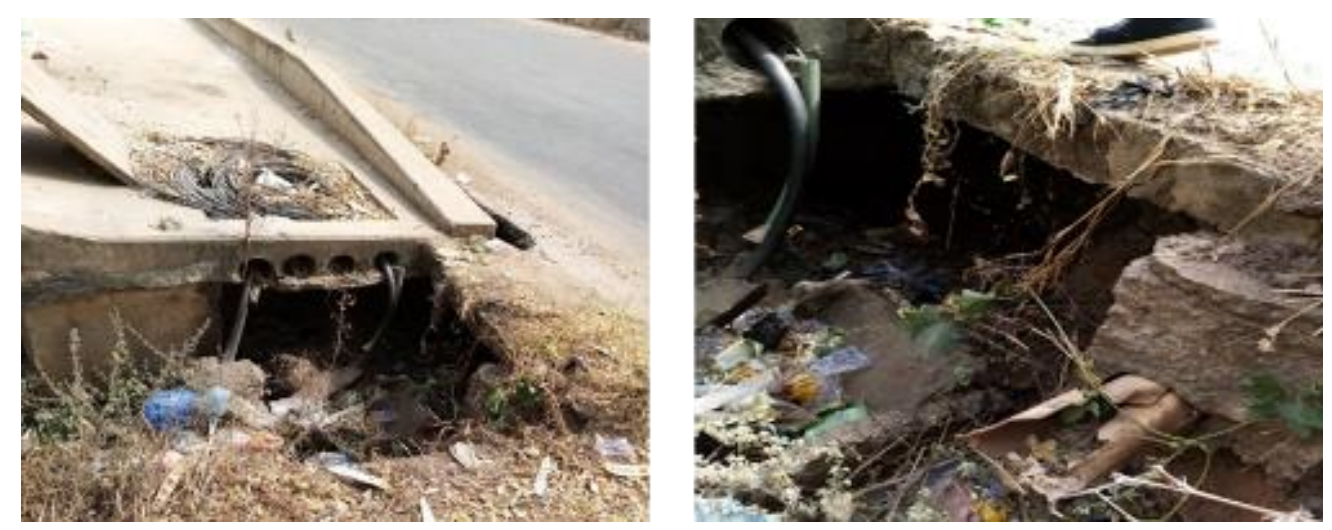

Plate 10 Erosion action exposing part of Abuja approach Abutment

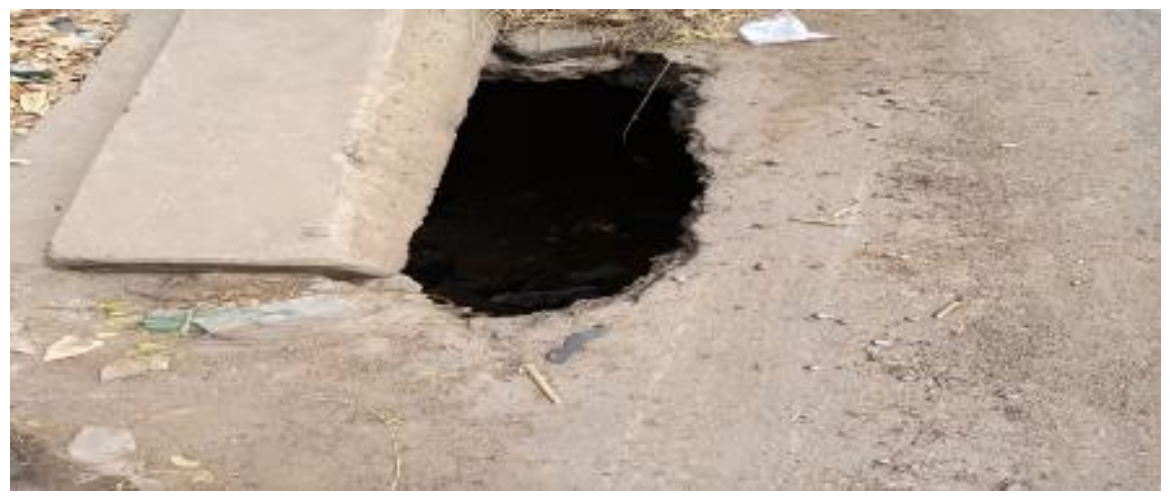

Plate 11 Erosion action exposing part of Abuja approach Abutment

\subsubsection{Bearings}

Visual inspections of the bridge bearings confirmed that the bearings are in good working condition. A typical inspection is shown in Plate 12 and 13. 


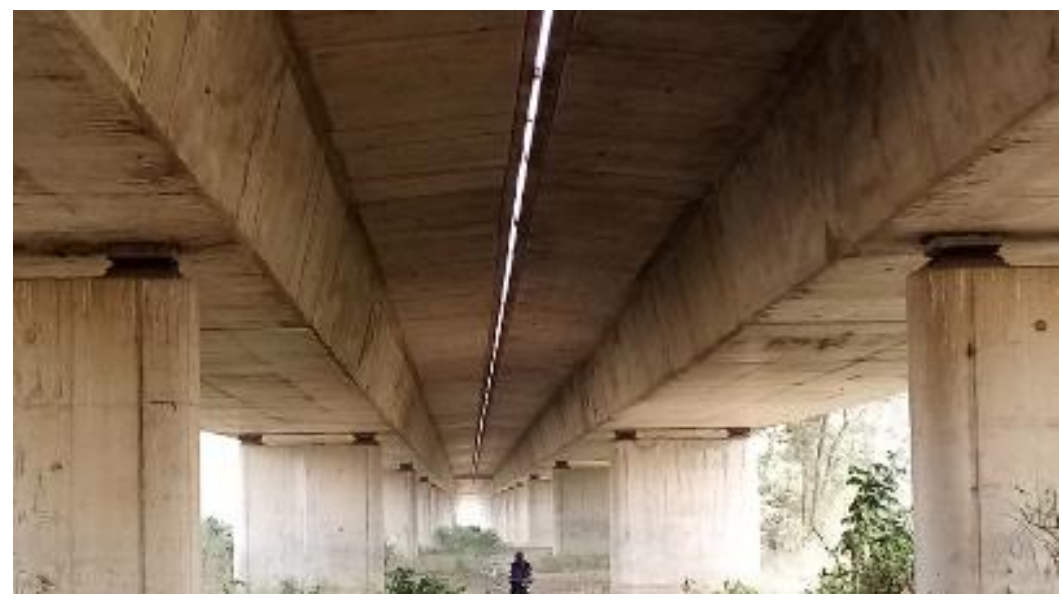

Plate 12 Drone captured images showing bearings of the Itobe Bridge

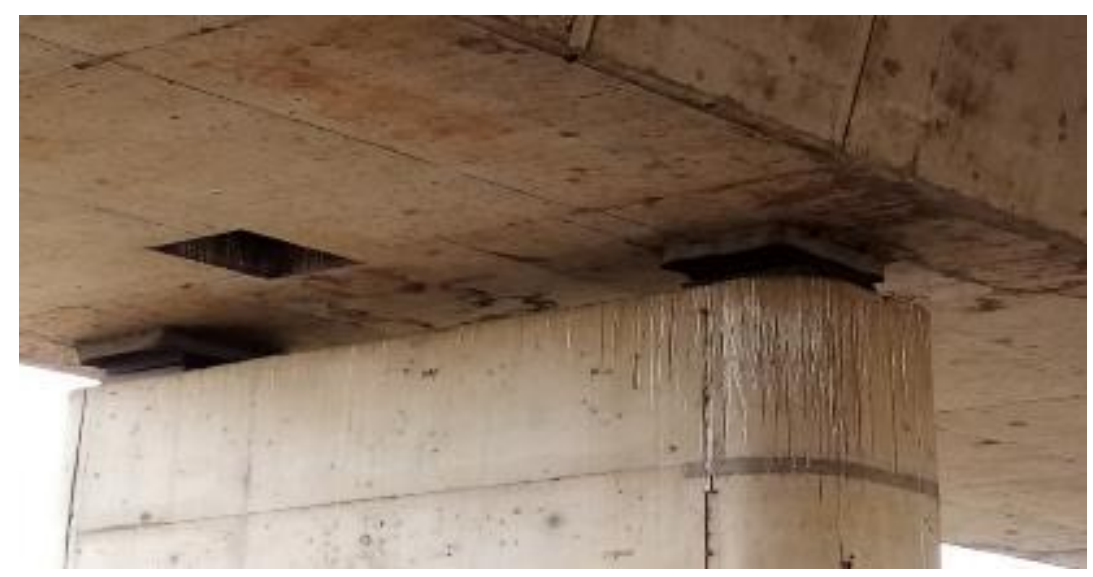

Plate 13 Showing bearings of the Itobe Bridge

\subsubsection{Cracks}

Minor vertical and diagonal cracks were noticed at the abutment's walls and walkway of Itobe Bridge. Cracking is an inherent aspect of reinforced concrete and, if properly controlled, should not be detrimental to the performance of the structure (Kozikowski and Suprenant, 2015).The cracks on the bridge were measured to be less than $0.5 \mathrm{~mm}$ wide as shown in Plate 12 to 13 which fall within acceptable value of $0.4 \mathrm{~mm}$ as stipulated in BS EN 1992-1-1:2004.

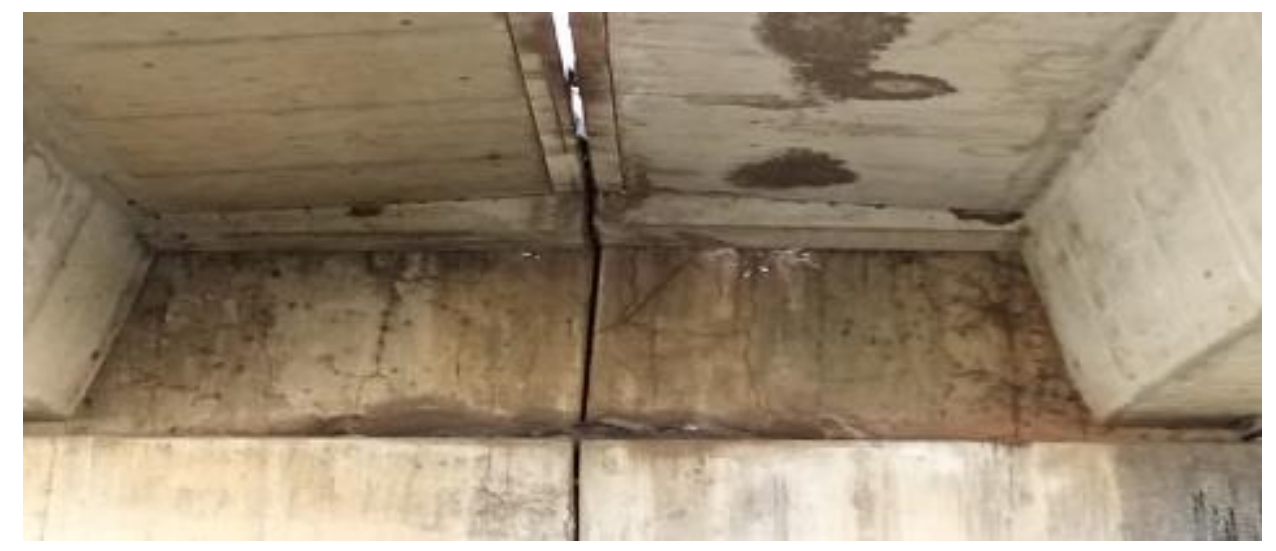

Plate 16 Minor cracks at the abutment of Abuja-Ayingba approach 


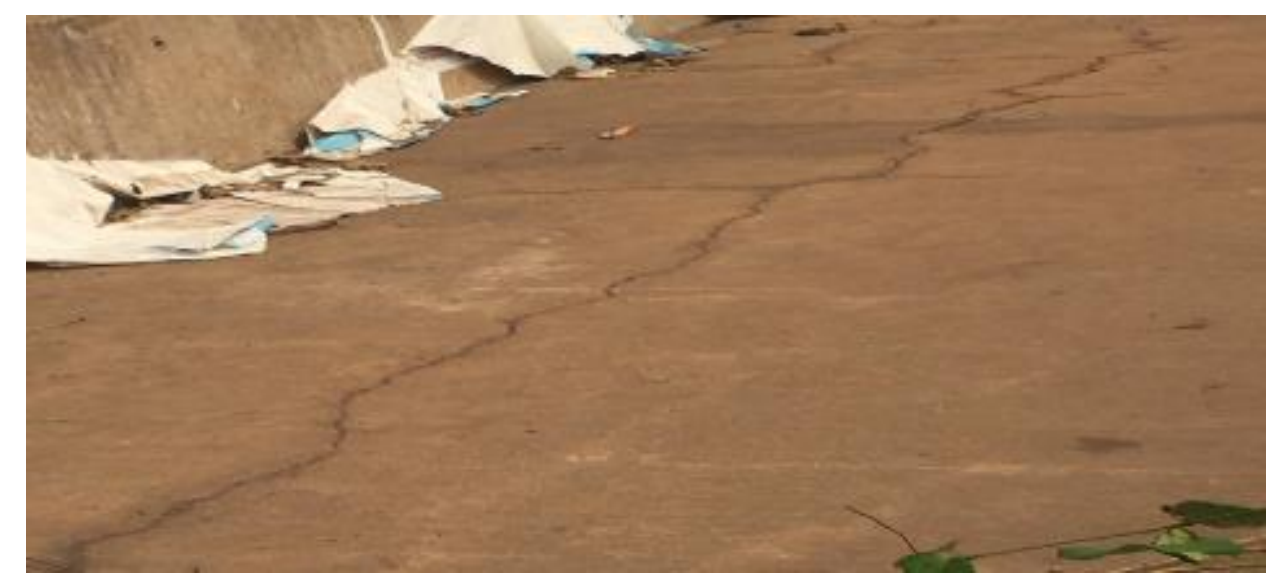

Plate 17 Cracks at walkway of the bridge on Ayingba - Abuja approach

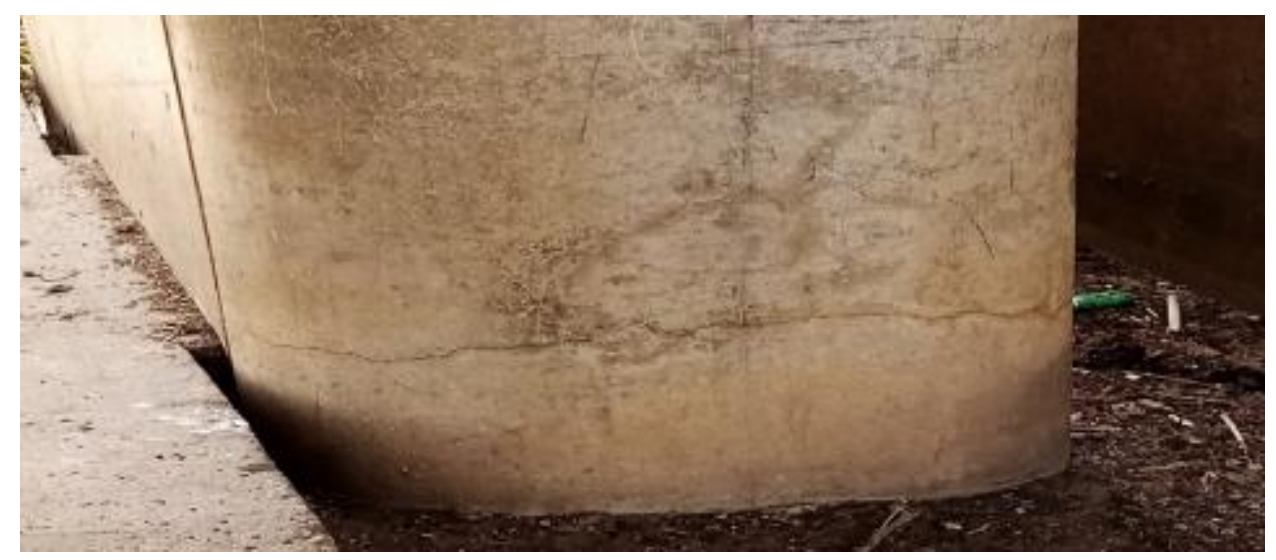

Plate 18 Crack identified on the pier foot of the Itobe Bridge.

\subsubsection{Spalling}

Spalling of concrete pedestrian walkway protector was observed as shown in Plate 19. Spalling is the peeling off of concrete cover thereby exposing the reinforcement which then leads to corrosion, and represents a serious defect in the concrete, in that the reinforcement can become corroded. On Itobe Bridge spalling of concrete was observed at the top and soffit of the bridge deck which was as result of bush fire burning from beneath the bridge. The incidence occurred few months ago according to an eye witness account.

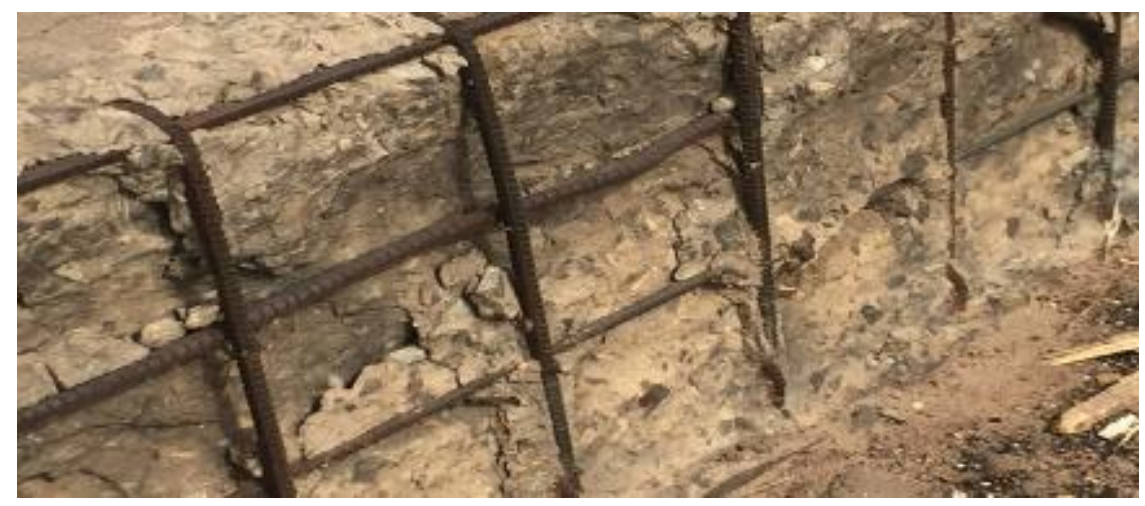

Plate 19 Concrete spalling on the pedestrian walkway protector. 


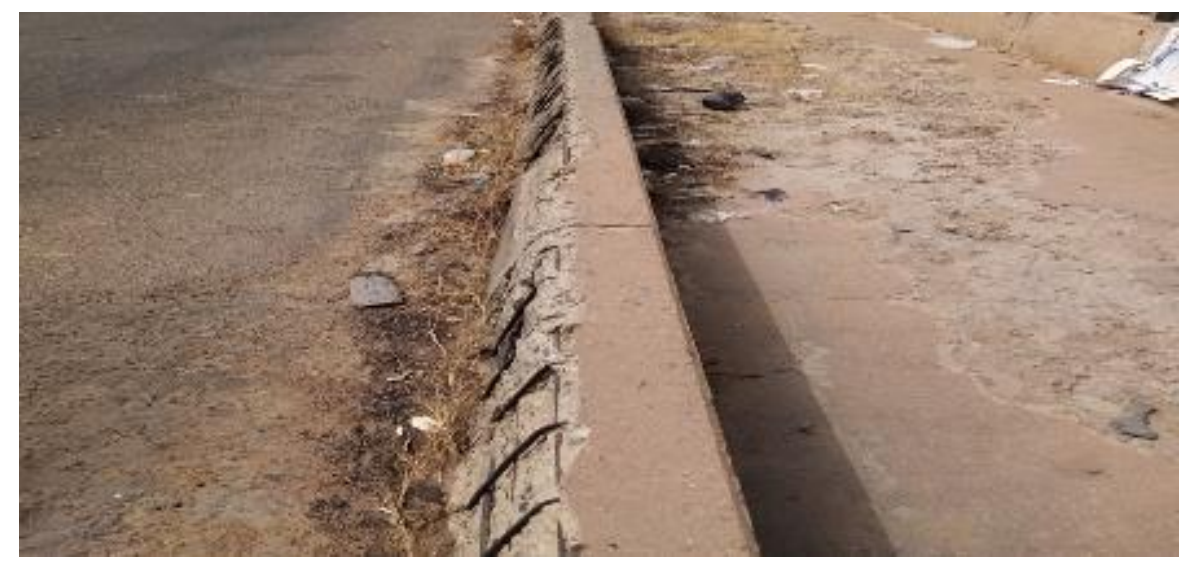

Plate 20 Spalling observed on pedestrian walkway section.

\subsubsection{Expansion Joints}

Expansion joints are one of the major components of bridge as it allows movement between the decks while accommodating shrinkage and temperature variations on reinforced or prestressed concrete. Itobe Bridge has a total of 8 expansion joints and it was observed that 7 were completely damaged. All the expansion joint were believed to be strip seal expansion joint. An elastomeric strip seal system consists of a preformed elastomeric gland mechanically locked into metallic edge rails generally embedded into the concrete deck on each side of an expansion joint gap. The strip seal expansion joint at the free moving end of the bridge deck (Ayingba approach) is in fair working condition, with little damages on the elastomeric strip seal as shown in plates 21 to 22 below. The damage of the elastomeric expansion joints as shown in plate 23 to 27 , it may be due to either aging or displacement of the bridge deck under loads. The width of the 7 damaged expansion joints gap were between the ranges of $47 \mathrm{~cm}$ to $53 \mathrm{~cm}$ wide.

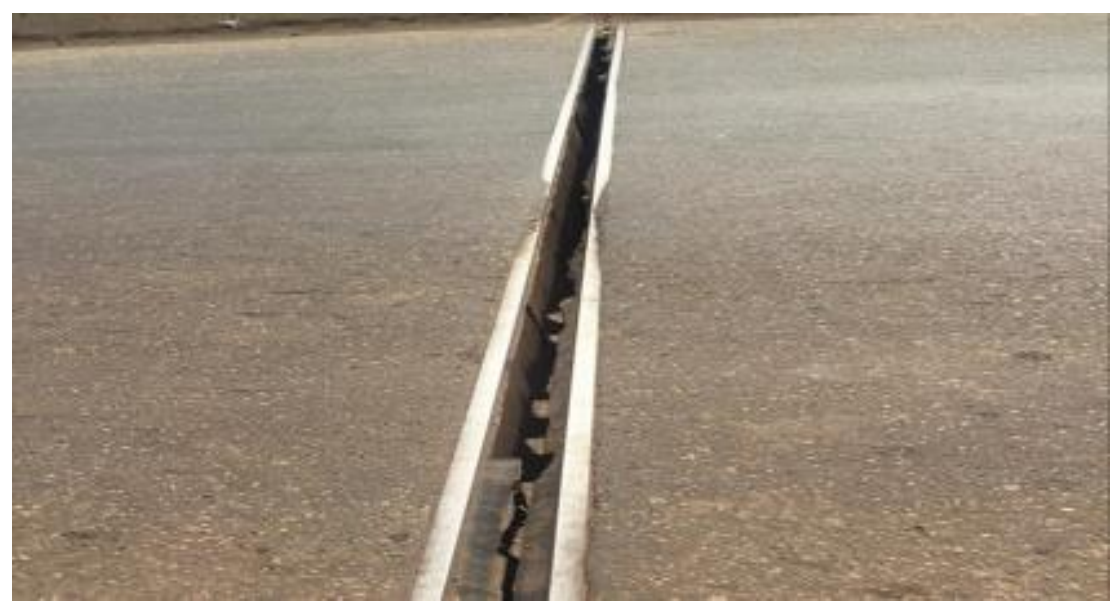

Plate 22 First expansion joint from Ayingba Approach with damaged elastomeric seal 
World Journal of Advanced Engineering Technology and Sciences, 2021, 02(02), 066-078

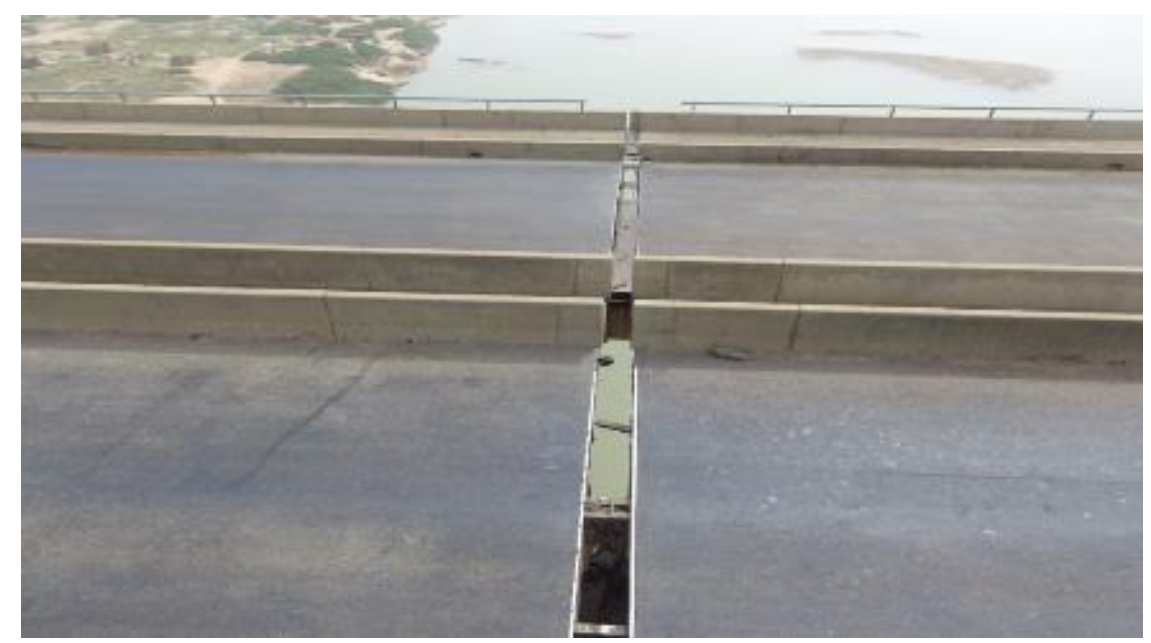

Plate 23 Drone image showing missing expansion joint cover of Itobe Bridge.

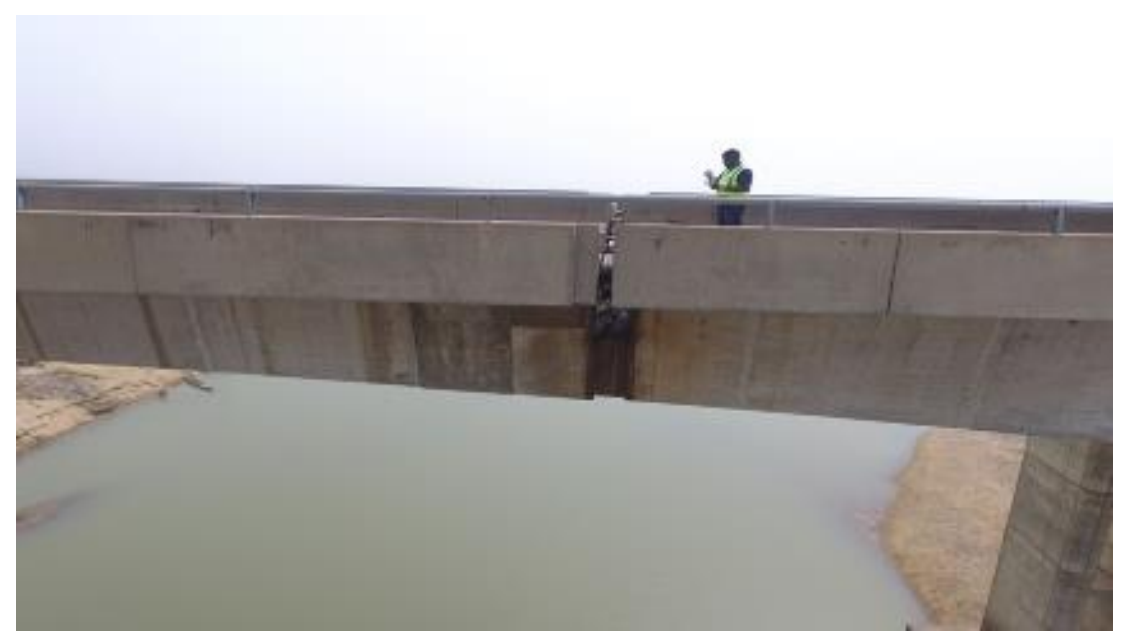

Plate 24 Drone image Showing missing expansion joint cover of Itobebridge

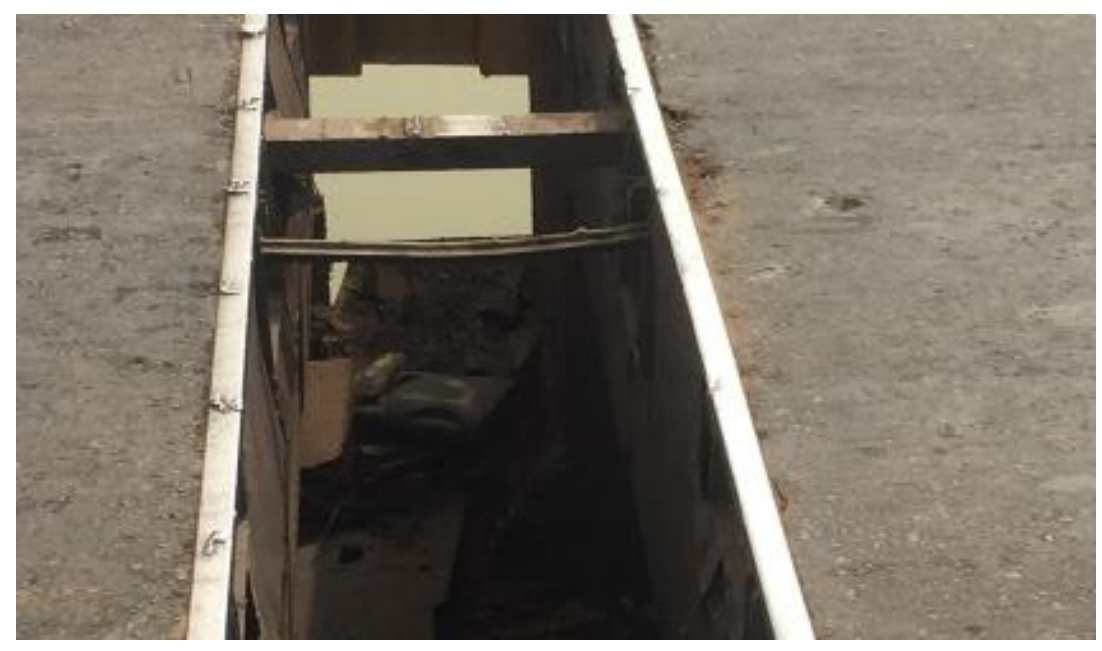

Plate 25 Showing opening of expansion joint 
World Journal of Advanced Engineering Technology and Sciences, 2021, 02(02), 066-078

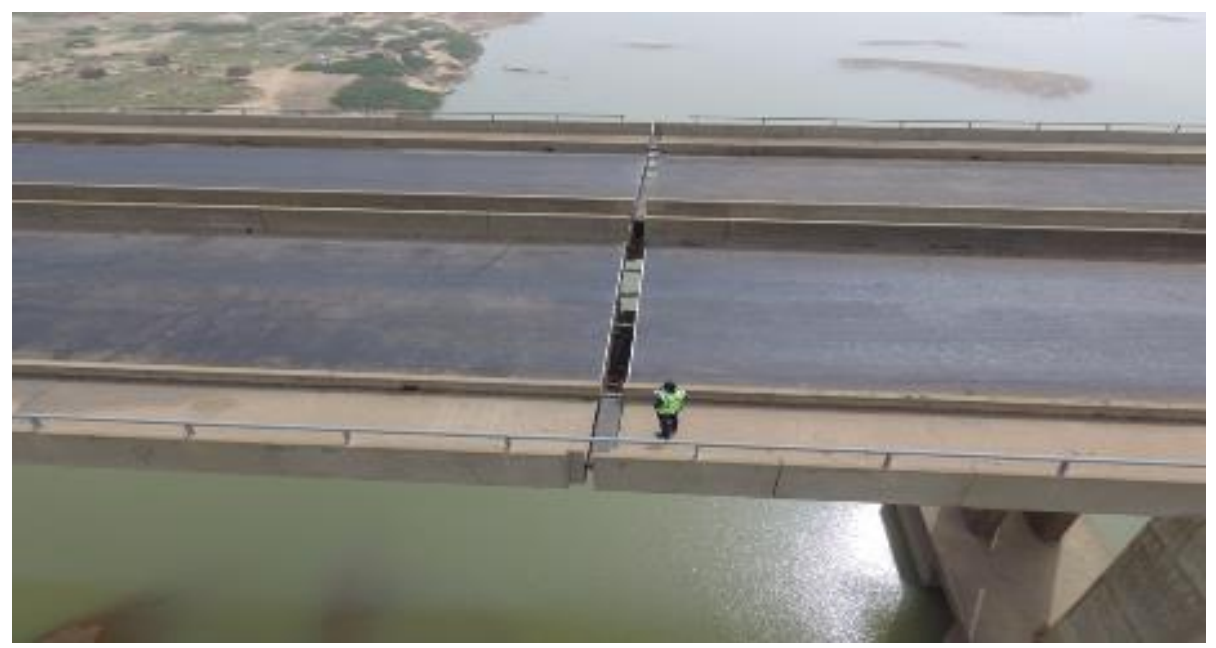

Plate 26Drone Image Showing opening of expansion joint

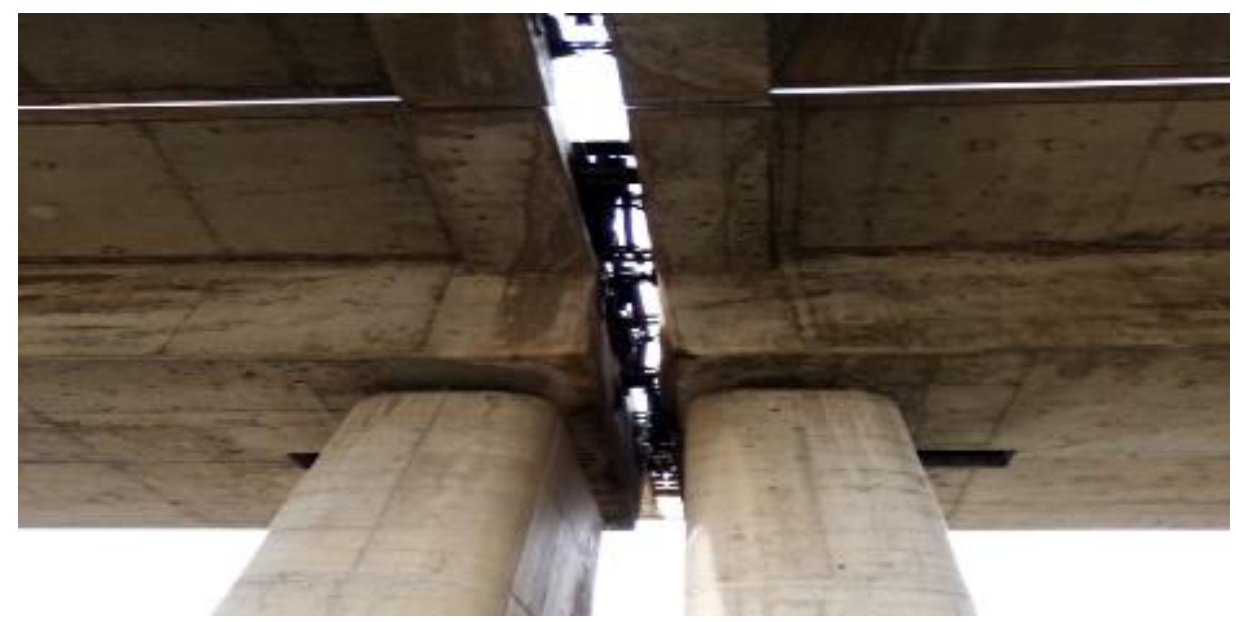

Plate 27 Image showing opening of expansion joint from the below the deck.

\subsubsection{Missing Steel handrails}

A total of about 800 meters length of steel pipe handrails were missing at both sides of Itobe Bridge as shown in Plate 24 and 25 below.
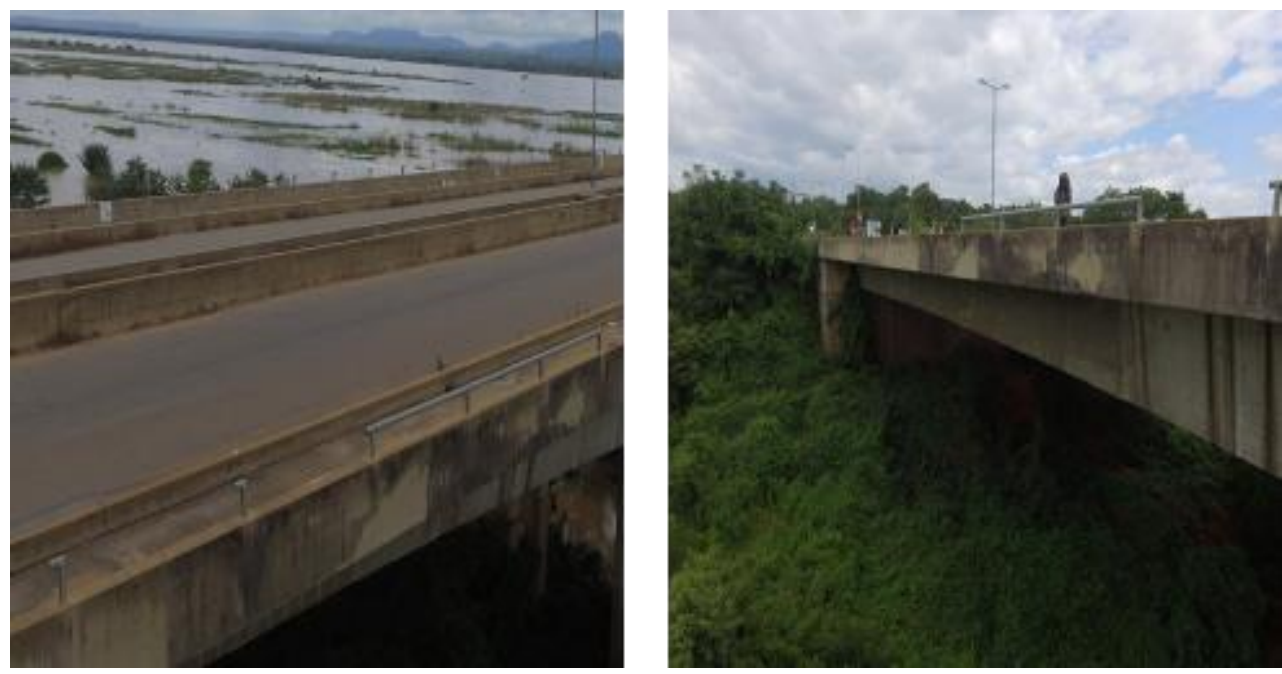

Plate 24 Image showing missing handrails. 


\subsubsection{Concrete Strength Test}

Concrete strength of the bridge was determined using rebound hammers. In practice, the results from this test are very dependent upon the surface condition and moisture content on the concrete as well as the ratio of aggregate cement paste. The results obtained are shown below. From the standard (Main Roads Western Australia level 3 Inspection Guidelines for concrete and steel bridges table 1) the concrete strengths are within the acceptable limits. Table 2 show the result obtained from Itobe Bridge.

Table 1 Apparent Quality of concrete from rebound values

\begin{tabular}{|c|c|}
\hline $\begin{array}{c}\text { Average Rebound } \\
\text { (Q Value) }\end{array}$ & Quality of Concrete \\
\hline$>40$ & Very Good \\
\hline $30-40$ & Good \\
\hline $20-30$ & Fair \\
\hline$<20$ & Poor and/or Delaminated \\
\hline
\end{tabular}

Table 2 Reinforced Concrete Bridge

\begin{tabular}{|c|c|c|c|c|c|}
\hline \multirow[t]{2}{*}{ Component } & \multirow[t]{2}{*}{ Location } & \multirow{2}{*}{$\begin{array}{l}\text { Compressive } \\
\text { Strength } \\
\left(\mathrm{N} / \mathbf{m m}^{2}\right)\end{array}$} & \multicolumn{3}{|c|}{ Rebound Hammer Values(Q) } \\
\hline & & & Average $Q$ Value & SD Q Value & Quality of Concrete. \\
\hline Column & 1 & 46.8 & 51.3 & 1.3 & Very Good \\
\hline Column & 3 & 41.7 & 52.2 & 1.7 & Very Good \\
\hline Column & 4 & 46.9 & 51.4 & 2.9 & Very Good \\
\hline Column & 5 & 45.3 & 49.8 & 4.6 & Very Good \\
\hline Abutment & Ayinba approach & 38.3 & 41.6 & 2.9 & Very Good. \\
\hline Abutment & Abuja approach & 32.9 & 43.3 & 1.6 & Very Good \\
\hline
\end{tabular}

\section{Conclusion}

From the visual and non-destructive structural assessment of the bridge, it can be deduced that:

- The compressive strength test result of the selected bridge elements shows that they are very good.

- The compressive strength test result of the selected bridge elements were between $32.9-46.9 \mathrm{~N} / \mathrm{mm}^{2} \mathrm{which}$ falls within the category of very good as stipulated in Main Roads Western Australia level 3 Inspection Guidelines for concrete and steel bridges.

- Minor deterioration of the bridge deck has progressed to the point where spalling has taken place.

- The spalling of the reinforced concrete deck was as a result of the extensive bush fire incidence.

- Seven out of eight expansion joint devices are damaged therefore exposing the elements of the structure that are otherwise protected by the joint devices. The openings about $47 \mathrm{~cm}-53 \mathrm{~cm}$ becomes a conduit by which moisture, abrasives, chemicals, and other debris are deposited on the superstructure and substructure below the opening, thereby causing extensive damage.

- The damage of the elastomeric expansion joints may be due to either aging or displacement of the bridge deck under vehicular loading.

- The cracks on the bridge were measured to be less than $0.5 \mathrm{~mm}$ wide which fall within acceptable value of 0.4 mm as stipulated in BS EN 1992-1-1:2004. 
- The bridge is safe for vehicular movement, however proper maintenance needs to be carried out urgently.

- A little vibrations were observed from the top of the deck.

\section{Recommendations}

- Lengthening and desilting of the short blocked drainage pipes which are directly discharging water on the concrete deck should be done in order to prevent further corrosion of the deck.

- The expansion joints should be fixed with proper elastomeric or steel strip materials to protect the structure from further deterioration.

- Expansion joint devices are highly susceptible to vehicular impact that results as a consequence of their inherent discontinuity hence the need for more frequent routing maintenance.

- Maintenance works required to seal cracks on the reinforced concrete abutment and piers should be carried out.

- Maintenance works required to repair the damaged parts of the concrete deck by thorough cleaning of the surface to remove all deteriorated concrete down to sound concrete and building the surface back to grade.

- The missing steel pipe handrails on the reinforced concrete bridge needs to be replaced and properly anchored to the deck.

- The use of sheet piles filled with compacted sand or gabions should be provided around the exposed piles cap to protect further deterioration of the foundations.

- The eroded embankment should be filled and compacted with the right fill materials and also shoreline protection measures should be deployed to protect the bridge embankment.

- There is need for monitoring after six months to re-evaluate the situation; hence this report will form a baseline for comparison.

A frequency test should be carried out to determine if the vibration observed is within the bridge natural limit.

\section{Compliance with ethical standards}

\section{Acknowledgments}

We are very grateful to the Almighty that gave us the wisdom snd time to conduct carry out this study. Also, i would like to acknowledge our Director General/Chief Executive Office Prof Sasun Duna for his support. Secondly, thanks to our Institute Nigerian Building and Road Research Institue for giving us the platform and opportunity to conduct this research.

\section{Disclosure of conflict of interest}

All authors declare no conflict of interest is exist.

\section{References}

[1] National Bridge Inspection Standards. Bridge Inspectors Reference Manual:Basic Bridge Terminology. 2012.

[2] Tompsett A. Bridges Transport Infrastructure and Economic Geography on Mississippi and Ohio. 2014; 18602000.

[3] Roc A, Miklos K,David KN. Bridges. 2014.

[4] Iowa Department of Transport. Bridge Inspection. 2011.

[5] Design of Concrete Structures - Part 1-1: General Rules and Rules for Buildings. 2014; 225.

[6] Kozikowski RL, Suprenant BA. Controlling Early-Age Cracking in Mass Concrete. Concrete International. 2015; 37(3): 59-62.

[7] Samuel O Oni. Hydrogeological Investigation For Groundwater Potentials In Ajaokuta Area, Kogi State Nigeria Using Electrical Resistivity Surveys. 2014.

[8] GSN. The geology of Lokoja - Auchi Area: Explanation notes on sheet 62. Geol. Survey Report. 1986; 38:71. 